\title{
Adhesion of Candida albicans to oral streptococci is promoted by selective adsorption of salivary proteins to the streptococcal cell surface
}

\author{
Justin M. O’Sullivan, † Howard F. Jenkinsonł and Richard D. Cannon
}

Department of Oral Sciences and Orthodontics, University of Otago, PO Box 647, Dunedin, New Zealand

\author{
Author for correspondence: Justin M. O'Sullivan. Tel: +44 1227764 000. Fax: +44 1227763912. \\ e-mail: jmo@ukc.ac.uk
}

\begin{abstract}
Adhesion of Candida albicans to saliva-coated surfaces is an important early step in the colonization of the oral cavity. C. albicans cells also adhere to several species of oral streptococci including Streptococcus gordonii, Streptococcus oralis and Streptococcus sanguinis in what are believed to be multi-modal interactions. It is now demonstrated that incubation of streptococcal cells of these species with human parotid saliva further promotes the adhesion of C. albicans cells by up to 2-3-fold. Various species of streptococci were shown to adsorb different protein components of parotid saliva to their cell surfaces. The basic proline-rich proteins (bPRPs), to which $C$. albicans cells bind on nitrocellulose blot overlay, were strongly adsorbed to the surface of $S$. gordonii cells but not to $S$. oralis cells. Parotid saliva that was pre-adsorbed with $S$. gordonii cells and then applied to hydroxylapatite beads was $<50 \%$ effective at supporting adhesion of $C$. albicans compared with control (non-adsorbed) saliva, demonstrating that bPRPs are major pellicle receptors. C. albicans cells did not adsorb bPRPs from fluid-phase parotid saliva. Following size-exclusion chromatography of parotid saliva samples, pooled fractions enriched in bPRPs promoted maximal adhesion of C. albicans to $S$. gordonii cells. The results demonstrate that $C$. albicans cells recognize only surface-bound forms of bPRPs and suggest that these proteins adsorbed to enamel or to streptococcal surfaces promote $C$. albicans adhesion and oral colonization.
\end{abstract}

Keywords: co-adhesion, Candida albicans, streptococci, proline-rich proteins

\section{INTRODUCTION}

Candida albicans is an opportunistic human pathogen that colonizes the oral cavities of a large proportion of the population without causing disease (Odds, 1988; Cannon et al., 1995a; Cannon \& Chaffin, 1999). Under conditions of host immunosuppression, however, $C$. albicans can cause a number of mucosal infections, including oral candidiasis and Candida vulvovaginitis

\footnotetext{
† Present address: Research School of Biosciences, University of Kent at Canterbury, Canterbury CT2 7NJ, UK.

¥Present address: Department of Oral and Dental Science, University of Bristol, Bristol, UK.

Abbreviations: HA, hydroxylapatite; PRPs, proline-rich proteins; aPRPs, acidic proline-rich proteins; bPRPs, basic proline-rich proteins.
}

(Odds, 1988). Oral candidiasis is the collective term for a number of distinct clinical oral pathologies that include acute pseudomembranous candidiasis, erythematous candidiasis, chronic hyperplastic candidiasis, chronic atrophic candidiasis and angular cheilitis (Odds, 1988; Samaranayake, 1992). Chronic atrophic candidiasis (denture-induced stomatitis) is the most common clinical manifestation of oral candidiasis and occurs in up to $60 \%$ of denture wearers (Odds, 1988; Lynch \& Tenn, 1994).

The oral cavity comprises diverse micro-environments containing a range of surfaces to which microbial cells can adhere, including the teeth, epithelial mucosa and the nascent surfaces created as micro-organisms bind to existing biofilms (Whittaker et al., 1996). All these surfaces are coated with salivary glycoproteins that are selectively bound (Douglas \& Russell, 1984; 
Scannapieco et al., 1989; Nikawa \& Hamada, 1990; Edgerton et al., 1993; Newman et al., 1993; Rudney et al., 1995). Co-adhesion (the binding of planktonic microbial cells to surface-bound microbial cells) is an important mechanism in microbial cell growth and survival in the oral cavity, and may be modulated by salivary molecules.

C. albicans has been isolated from dentures (Arendorf \& Walker, 1979; Wright et al., 1985), dental plaque (Hodson \& Craig, 1972; Arendorf \& Walker, 1980) and from sites of periodontal disease (Slots et al., 1988; Rams \& Slots, 1991). Furthermore, adhesion of C. albicans to oral surfaces including buccal epithelial cells and acrylic (Verran \& Motteram, 1987; Branting et al., 1989) has been shown to be influenced by oral bacteria. Therefore, there is good in vivo and in vitro evidence for Candida interactions with bacterial biofilms. Holmes et al. (1995b) demonstrated that C. albicans cells coaggregate with, and co-adhere to, certain species of oral streptococci, and for some species, e.g. Streptococcus gordonii, salivary proteins enhance the interactions (Holmes et al., 1995a). Salivary-protein-enhanced coadhesion of oral bacteria has been frequently described (see Jenkinson \& Lamont, 1997) and the salivaenhanced binding of Streptococcus mutans to Actinomyces naeslundii, Streptococcus sanguinis and Streptococcus mitis is believed to be a significant factor in the development of early plaque (Lamont \& Rosan, 1990). However, few studies have identified the salivary components that enhance inter-microbial adhesion, or indeed that may inhibit co-adhesion (Stinson et al., 1992).

Several studies (Gibbons \& Hay, 1988; Gibbons et al., 1991) have demonstrated that the acidic proline-rich proteins (aPRPs) can promote the adherence of $A$. naeslundii and $S$. gordonii cells to apatitic surfaces. These studies concluded that the acidic PRP-1 protein was cryptic in nature due to the fact that it did not bind to the cell surface of A. naeslundii LY7 cells, but rather is only recognized as a receptor for A. naeslundii LY7 and $S$. gordonii Blackburn cells when immobilized onto an apatitic surface (Gibbons \& Hay, 1988; Gibbons et al., 1991). However, subsequent studies have shown that oral streptococci, when incubated with parotid saliva, adsorb salivary protein components including the aPRPs and some basic PRPs (bPRPs IB-1 to IB-9) onto their surfaces in a species- and strain-specific manner (Newman et al., 1993). Therefore, it is possible that some streptococci are able to recognize alternate forms of PRPs, either soluble or bound. This is analogous to the suggestion that streptococci are able to bind and differentiate between soluble and immobilized forms of salivary agglutinin (Jenkinson \& Demuth, 1997) and allows bacterial cell adhesion to salivary pellicles despite the excess soluble forms of the receptor in saliva.

Since we have previously identified the bPRP IB-6 and three other PRPs as possible pellicle receptors for $C$. albicans ATCC 10261 adhesion (O'Sullivan et al., 1997), we investigated the hypothesis that selective adsorption of bPRPs by streptococci may enhance C. albicans adhesion within oral biofilms.

\section{METHODS}

Strains and growth media. The streptococcal strains used included S. gordonii NCTC 7869 (Channon), S. gordonii DL1 (Challis) (Pakula \& Walczak, 1963), S. sanguinis ATCC 10556, S. mitis NCTC 10712, Streptococcus oralis 34 (from P. E. Kolenbrander, National Institutes of Health, Bethesda) and S. mutans NG8 (from A. S. Bleiweis, University of Florida, Gainesville). C. albicans ATCC 10261 was the yeast strain used in this study. Streptococcal cells were grown on TSBY agar $\left(1^{-1}: 20 \mathrm{~g}\right.$ trypticase soy broth, $5 \mathrm{~g}$ yeast nitrogen broth, $5 \mathrm{~g}$ glucose, $20 \mathrm{~g}$ agar $)$ or in $\mathrm{BHY}\left(\mathrm{l}^{-1}: 37 \mathrm{~g}\right.$ brain heart infusion, 5 g yeast extract) medium at $37^{\circ} \mathrm{C}$ in screw-capped tubes or bottles as stationary cultures (McNab et al., 1994). Late-exponential-phase cultures $\left(\mathrm{OD}_{600} 2\right.$, approx. $4 \times 10^{9}$ cells $\left.\mathrm{ml}^{-1}\right)$ were centrifuged $\left(6000 \mathrm{~g}, 4^{\circ} \mathrm{C}, 10 \mathrm{~min}\right)$ to pellet bacterial cells, which were then washed and prepared for assays as described below. C. albicans ATCC 10261 cells were grown in glucose salts biotin medium (GSB; Holmes \& Shepherd, 1988) at $30^{\circ} \mathrm{C}$ with vigorous shaking and collected from exponential-phase cultures by centrifugation $(4000 \mathrm{~g}$, 10 min, $4^{\circ} \mathrm{C}$ ) (O’Sullivan et al., 1997).

Collection and fractionation of parotid saliva. Stimulated parotid saliva samples were collected from six donors using a modified Carlson-Crittenden device (Shannon et al., 1962) and stored on ice. The following proteinase inhibitors were added to the saliva samples (final concentrations): PMSF $(1 \mathrm{mM})$; bisulphite $(10 \mathrm{mM})$; benzamidine/HCl $(2 \mathrm{mM})$; pepstatin A $(2 \cdot 9 \mu \mathrm{M})$; and aprotinin $(0 \cdot 3 \mu \mathrm{M})$. Samples were then pooled and clarified by centrifugation $\left(12000 \mathrm{~g}, 4^{\circ} \mathrm{C}\right.$, $15 \mathrm{~min})$. For fractionation, saliva $(60 \mathrm{ml})$ was freeze-dried, suspended in water and applied to a Sephacryl S200 column (XK 26/100; Pharmacia). Fractions were collected and characterized as previously described (O'Sullivan et al., 1997).

Adhesion of C. albicans to saliva-coated hydroxylapatite (HA) beads. C. albicans cells were radioactively labelled with $\left[{ }^{35} \mathrm{~S}\right]$ methionine [New England Nuclear; $4.3 \times 10^{13} \mathrm{~Bq}$ $\left.\mathrm{mmol}^{-1}\left(1175 \mathrm{Ci} \mathrm{mmol}^{-1}\right)\right]$ to a specific radioactivity of $0 \cdot 036 \pm 0.017$ c.p.m. per cell as described previously (O'Sullivan et al., 1997). Labelled cells were washed and suspended in $\mathrm{KCl}$ buffer $\left(2 \mathrm{mM} \mathrm{KH_{2 }} \mathrm{PO}_{4}, 2 \mathrm{mM} \mathrm{K}_{2} \mathrm{HPO}_{4}\right.$, $5 \mathrm{mM} \mathrm{KCl}, 1 \mathrm{mM} \mathrm{CaCl}_{2}, \mathrm{pH} \mathrm{6.5)}$ and numbers of C. albicans cells adhering to parotid-saliva-coated HA beads $(20 \mathrm{mg}$; Macrosorb C, Phase Sep) were measured as described by Cannon et al. (1995b).

SDS-PAGE and electroblotting. SDS-PAGE was performed according to the method of Laemmli (1970) through $12.5 \%$ (w/v) acrylamide gels. The apparent molecular mass of proteins was estimated using pre-stained protein markers (15.4-200 kDa; Gibco-BRL). Sample protein concentrations were determined using a modified Bradford assay (Bio-Rad). Proteins were electroblotted (Towbin et al., 1979) onto nitrocellulose membranes (Hybond-C; Amersham) for use in blot overlay assays. Transfer conditions were $100 \mathrm{~V}, 1.5 \mathrm{~h}$, at $4{ }^{\circ} \mathrm{C}$ and membranes were stored in plastic wrap at $4{ }^{\circ} \mathrm{C}$ until use.

Blot overlay assay. The binding of C. albicans ATCC 10261 cells to electrophoretically separated parotid saliva proteins, immobilized on nitrocellulose membranes, was determined as previously described (O’Sullivan et al., 1997). Salivary proteins on blot membranes were first visualized by staining them with $0.2 \%(\mathrm{w} / \mathrm{v})$ Ponceau $\mathrm{S}$ in $1 \%(\mathrm{v} / \mathrm{v})$ acetic acid for $5 \mathrm{~min}$, followed by four washes with $1 \%(\mathrm{v} / \mathrm{v})$ acetic acid. The membranes were destained with two washes $\left(30 \mathrm{~min}, 20^{\circ} \mathrm{C}\right.$ ) of PBS $\left(1^{-1}: 8.5 \mathrm{~g} \mathrm{NaCl}, 0.3 \mathrm{~g} \mathrm{KH}_{2} \mathrm{PO}_{4}, 0.6 \mathrm{~g} \mathrm{Na}_{2} \mathrm{HPO}_{4}, \mathrm{pH}\right.$ 
$7 \cdot 5)$ and blocked with $5 \%(\mathrm{w} / \mathrm{v})$ BSA in $\mathrm{KCl}$ buffer $(2 \mathrm{~h}$, $20{ }^{\circ} \mathrm{C}$ ). Membranes were incubated with radioactively labelled C. albicans cells $\left[30 \mathrm{ml}, 1 \cdot 1 \times 10^{7}\right.$ cells $\left.(\mathrm{ml} \mathrm{KCl} \mathrm{buffer})^{-1}\right]$ for $18 \mathrm{~h}$ at $4^{\circ} \mathrm{C}$ with reciprocal shaking $\left(70 \mathrm{~min}^{-1}\right)$, washed four times in PBS containing $0.1 \%(\mathrm{v} / \mathrm{v})$ Tween 20 to remove nonspecifically bound $C$. albicans cells and air-dried prior to exposure to X-ray film.

Fluid-phase adsorption assay. Proteins were adsorbed from parotid saliva by microbial cells following a modification of the method described by Newman et al. (1993). Streptococcal or candidal cells were harvested from cultures by centrifugation, washed with $\mathrm{KCl}$ buffer as described above, and suspended in $\mathrm{KCl}$ buffer at a concentration of $8 \times 10^{7}$ streptococcal cells $\mathrm{ml}^{-1}$ or $4 \cdot 4 \times 10^{7}$ C. albicans cells $\mathrm{ml}^{-1}$. Bacterial or yeast cell suspensions $(0.3 \mathrm{ml})$ were added to parotid saliva diluted to $0.5 \mathrm{mg}$ protein $\mathrm{ml}^{-1}$ with $\mathrm{KCl}$ buffer $(0.6 \mathrm{ml})$ and incubated with end-over-end rotation (9 r.p.m.) at $20^{\circ} \mathrm{C}$ for $1 \mathrm{~h}$. Cells were sedimented by centrifugation $\left(2900 \mathrm{~g}, 4^{\circ} \mathrm{C}, 10 \mathrm{~min}\right)$ and the supernatant was collected and analysed by SDS-PAGE or retained as pre-adsorbed parotid saliva samples for use in blot overlay and adhesion assays.

Coadhesion assay. C. albicans-streptococcal co-adhesion assays were performed essentially as described by Holmes et al. (1995a, 1996). Streptococcal or candidal cells were washed and suspended at a concentration of $4 \times 10^{8}$ cells $\mathrm{ml}^{-1}$ or $4.4 \times 10^{7}$ cells $\mathrm{ml}^{-1}$, respectively, in TNMC $(1 \mathrm{mM}$ Tris $/ \mathrm{HCl}$, $\mathrm{pH} 8 \cdot 0$, containing $0.15 \mathrm{M} \mathrm{NaCl}, 1 \mathrm{mM} \mathrm{MgCl}$ and $1 \mathrm{mM}$ $\left.\mathrm{CaCl}_{2}\right)$. Bacterial or yeast cell suspensions $(50 \mu \mathrm{l})$ were dispensed into 96-well microtitre plates (Scintistrip, Wallac Oy), centrifuged $\left(800 \mathrm{~g}, 5 \mathrm{~min}, 20^{\circ} \mathrm{C}\right)$ to immobilize cells, and the supernatant was discarded. The wells were washed twice $[150 \mu \mathrm{l}, 0.05 \%, \mathrm{v} / \mathrm{v}$, Tween 20 in TNMC buffer (TweenTNMC)] and incubated with Tween-TNMC (150 $\mu \mathrm{l}, 16 \mathrm{~h}$, $4{ }^{\circ} \mathrm{C}$ ). The liquid was aspirated from the wells and 50-150 $\mu \mathrm{l}$ portions of saliva samples (diluted in TNMC buffer) were added and incubated at $20^{\circ} \mathrm{C}$ for $1 \mathrm{~h}$. The wells were washed twice $(150 \mu \mathrm{l}$ Tween-TNMC) and then incubated with radiolabelled C. albicans cells $\left[0 \cdot 1 \mathrm{ml}, 2 \cdot 5 \times 10^{6}\right.$ cells (ml TNMC buffer $)^{-1}, 20^{\circ} \mathrm{C}, 2 \mathrm{~h}$, with shaking (50 r.p.m.)]. Liquid was aspirated from the wells, which were washed four times (150 $\mu \mathrm{l}$ Tween-TNMC, $10 \mathrm{~min}$ ) before allowing them to dry $\left(37^{\circ} \mathrm{C}, 1 \mathrm{~h}\right)$. The plastic well strips were snap-separated and bound radioactivity was counted using a 1450 Microbeta Plus liquid scintillation counter (LKB, Wallac Oy).

\section{RESULTS}

\section{Effect of parotid saliva on C. albicans co-adhesion}

The co-adhesion of C. albicans ATCC 10261 cells to immobilized streptococcal cells was measured in a microtitre well assay. Substantial proportions of input yeast cells (24-49\%) adhered to S. gordonii, S. oralis or $S$. sanguinis cells, while much fewer cells bound to $S$. mutans cells (Fig. 1). C. albicans demonstrated low-level binding to immobilized homologous candidal cells. $S$. oralis 34 and S. sanguinis ATCC 10556 supported greater numbers of C. albicans bound (up to $49 \%$ of input cells) compared with $S$. gordonii DL1 cells, confirming previous results (Holmes et al., 1995a). Preincubation of streptococcal cells with parotid salivary proteins (equivalent to approximately 2 pg protein per microbial cell) increased markedly the binding of $C$. albicans to $S$. gordonii (2-3-fold) and also significantly

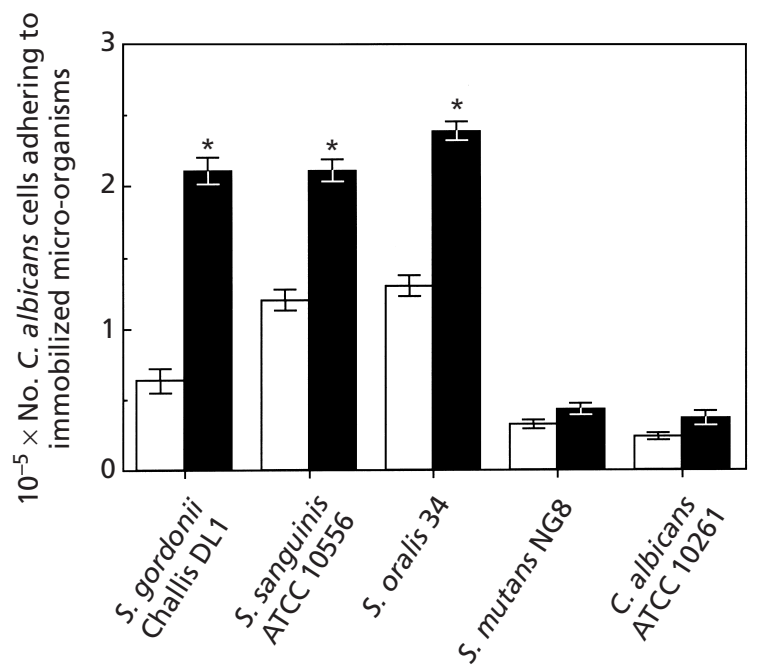

Immobilized micro-organism

Fig. 1. Stimulation of C. albicans ATCC 10261 cell adhesion to streptococci by parotid saliva. Streptococcal or C. albicans cells $\left(2 \times 10^{7}\right.$ or $2.2 \times 10^{6}$, respectively) immobilized to microtitre plate wells were incubated with diluted parotid saliva (black bars; equivalent to approx. $2 \mathrm{pg}$ salivary protein per cell) at $20^{\circ} \mathrm{C}$ for $1 \mathrm{~h}$, or with buffer alone (white bars), prior to addition of radiolabelled C. albicans cells $\left(2.6 \times 10^{5}\right.$ cells per well). Representative results, which are the means $( \pm S D)$ of triplicates performed on the same batch of cells, are shown. Background binding to buffer-treated wells was $2.6 \pm 2.08 \times 10^{3}$ C. albicans cells. * Significant increase in adherence $(P<0.005$, Student's $t$-test).

$(P<0.005)$ increased binding of $C$. albicans cells to $S$. sanguinis ATCC 10556 and S. oralis 34 cells (Fig. 1). Saliva did not, however, significantly affect the binding of yeast cells to $S$. mutans or to homologous C. albicans cells (Fig. 1). Preliminary, as well as subsequent, experiments showed that this salivary stimulation of the numbers of Candida binding to streptococci was dosedependent (saturating at approximately 1.4 pg salivary protein per $S$. gordonii cell), and in all instances was maximal at the concentration of salivary proteins (equivalent to approximately 2 pg per bacterial cell) used in the experiment shown in Fig. 1. These results indicated that streptococcal cells selectively adsorbed salivary protein receptors for C. albicans adhesion and therefore we proceeded to determine the nature of these receptors.

\section{Adsorption of salivary proteins by streptococcal cells}

To identify the protein components depleted from saliva by streptococci, adsorbed saliva samples were analysed by SDS-PAGE and the candidal adhesion receptors remaining were determined by blot overlay. Incubation of saliva with S. gordonii NCTC 7869 (Fig. 2) or DL1 (data not shown) cells caused a depletion in protein bands of apparent molecular masses 72, 42, 32, 28, 24, 16.5 and $15 \mathrm{kDa}$, compared with saliva samples incubated under identical conditions without bacteria added. 
(a)

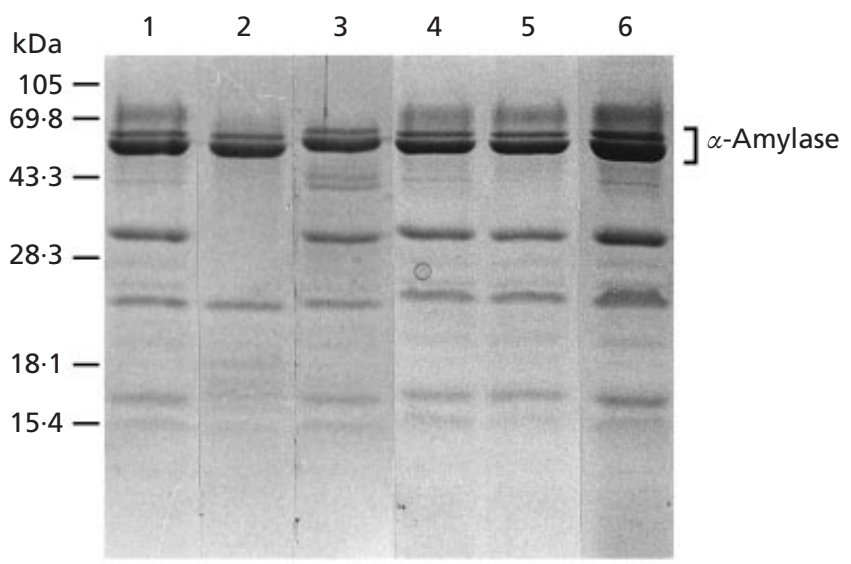

(b)

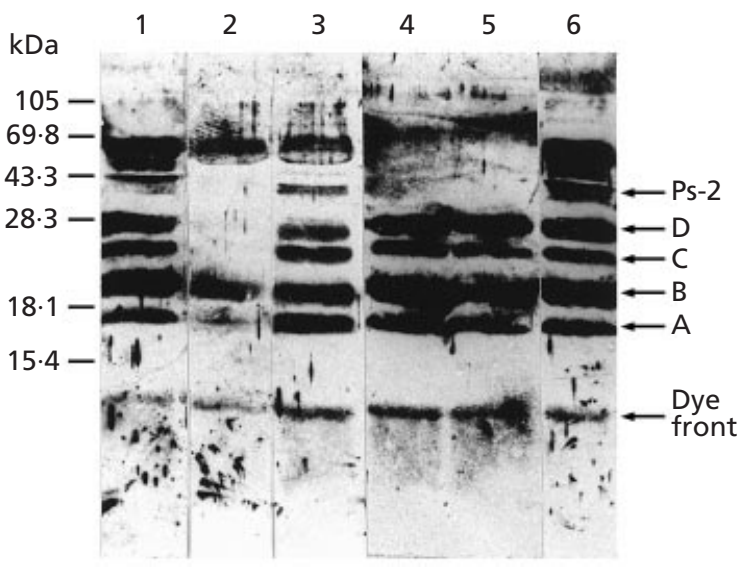

Fig. 2. Selective adsorption of salivary proteins by oral streptococci. Clarified parotid saliva was incubated with streptococcal or C. albicans ATCC 10261 cells at $20^{\circ} \mathrm{C}$ for $1 \mathrm{~h}$. Microbial cells were sedimented by centrifugation and supernatants ( $20 \mu \mathrm{l}$ per lane) were subjected to SDS-PAGE. Gels were either stained with Coomassie blue R250 or electroblotted onto nitrocellulose membranes which were then incubated with radiolabelled $C$. albicans cells $\left(1.03 \times 10^{7}\right.$ cells $\left.\mathrm{ml}^{-1}\right)$. (a) Coomassie-stained gel; (b) autoradiogram of corresponding blot overlay. Micro-organisms used to adsorb salivary proteins were: C. albicans ATCC 10261, lane 1; S. gordonii NCTC 7869, lane $2 ;$ S. oralis 34 , lane 3 ; S. mitis NCTC 10712, lane $4 ;$ S. sanguinis ATCC 10556, lane $5 ; \mathrm{KCl}$ buffer control, lane 6 . A-D are bands previously identified as receptors for $C$. albicans adherence (O'Sullivan et al., 1997) and Ps-2 is the basic PRP-2. The experiment was carried out three times and representative results are shown.

S. oralis 34 or S. sanguinis ATCC 10556 cells also removed the 72 or $42 \mathrm{kDa}$ protein bands, respectively (Fig. 2a, lanes 3 and 5). By contrast, incubation of saliva with cells of $S$. mitis NCTC 10712, S. mutans NG8 or C. albicans ATCC 10261 had no significant effects on the protein profiles (Fig. 2). S. gordonii binds $\alpha$-amylase with high affinity from fluid-phase parotid saliva (Rogers et al., 1998; Scannapieco et al., 1989), but under the assay conditions described the putative $\alpha$-amylase was not completely removed by any strain tested (see

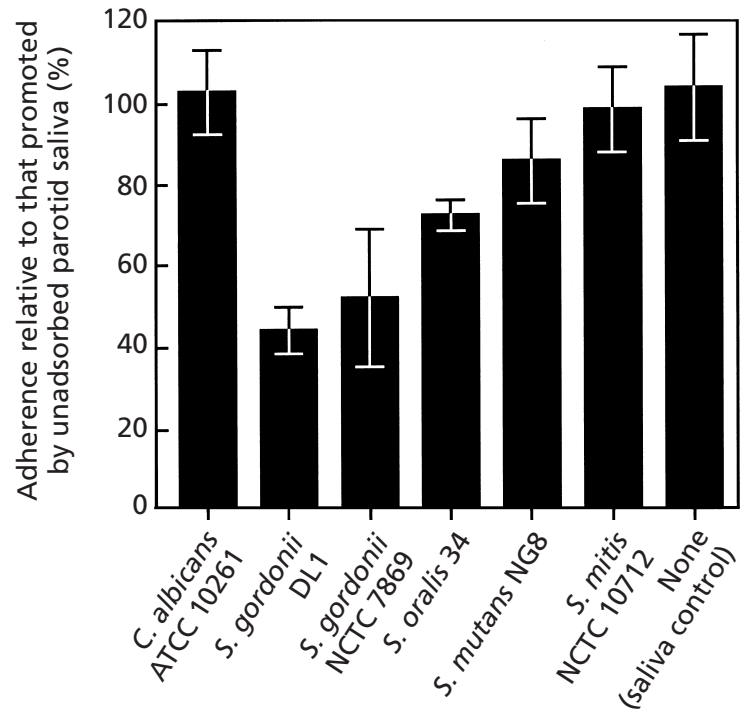

Micro-organism used to pre-adsorb saliva

Fig. 3. Effect of pre-adsorbing saliva with oral micro-organisms on subsequent ability to support $C$. albicans adhesion to HA beads. Pre-adsorbed saliva samples were used to coat HA beads and the numbers of $C$. albicans ATCC 10261 cells binding (input $2 \cdot 7 \pm 0 \cdot 14 \times 10^{6}$ ) were measured. Results are expressed as a percentage of the binding promoted by the unadsorbed parotid saliva sample $\left(9.72 \pm 1.35 \times 10^{5}\right.$ cells). Results are the means $( \pm S D)$ of triplicates performed on at least one batch of cells.

Fig. 2). This was confirmed by demonstrating the presence of $\alpha$-amylase activity, using starch agar plates (Douglas et al., 1990), in saliva samples that had been pre-incubated with streptococcal cells (data not shown).

We have previously identified four salivary bPRPs (denoted band A, $17 \mathrm{kDa}$; band $\mathrm{B}, 20 \mathrm{kDa}$; band $\mathrm{C}$, $24 \mathrm{kDa}$; and band $\mathrm{D}, 27 \mathrm{kDa}$ ) that are bound by $\mathrm{C}$. albicans cells in blot overlay assays (O'Sullivan et al., 1997). In addition, C. albicans cells also bind to the bPRP Ps-2 (43 kDa). Following incubation of parotid saliva samples with $S$. gordonii cells, no binding of $C$. albicans cells to band $\mathrm{C}$ or band D was observed (Fig. $2 \mathrm{~b})$ and the $43 \mathrm{kDa}$ (Ps-2) receptor for C. albicans present in untreated saliva (Fig. 2) was also removed. Binding of C. albicans cells to band A (17 kDa, bPRP IB6; O'Sullivan et al., 1997) and band B (20 kDa) was also reduced (Fig. 2b). Pre-incubation of parotid saliva with S. mitis NCTC 10712 or S. sanguinis ATCC 10556 also removed the $43 \mathrm{kDa}$ C. albicans ATCC 10261 adhesion receptor Ps-2 (Fig. 2b, lanes 4 and 5). Incubation of parotid saliva with S. oralis, C. albicans ATCC 10261 (Fig. 2b) or with S. mutans (data not shown) did not alter the binding profiles of C. albicans in blot overlay assays. These results demonstrated that the various streptococcal species adsorbed different salivary proteins to their cell surfaces, and suggested that the adsorption of bPRPs by $S$. gordonii could account for the C. albicans-S. gordonii co-adhesion-promoting ac- 


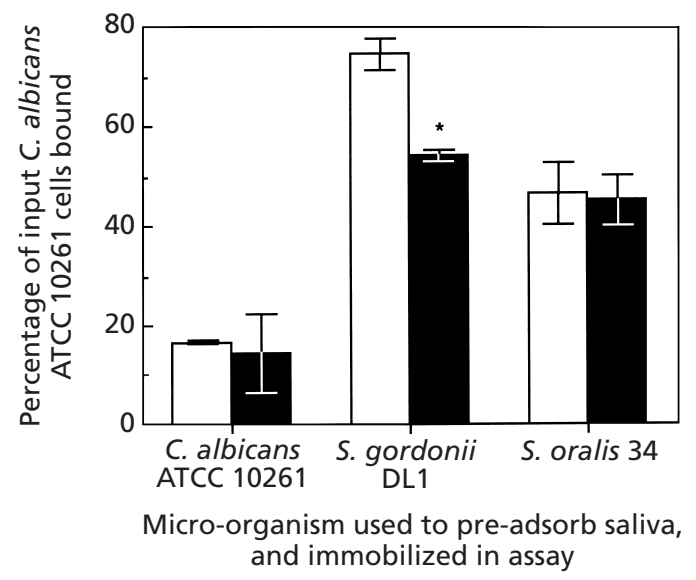

Fig. 4. Effect of pre-adsorbing parotid saliva on the ability to support C. albicans cell adhesion to immobilized microorganisms. Saliva was pre-adsorbed with streptococcal or $C$. albicans cells and then used in microtitre assays to measure adhesion of C. albicans cells to fresh, immobilized, microorganisms. Numbers are the percentage of the input $C$. albicans ATCC 10261 cells $\left(2 \cdot 6 \pm 10^{5}\right.$ per well) bound, and are the means of quadruplicates. White bars, unadsorbed saliva; black bars, pre-adsorbed saliva. *Significant decrease in adherence $(P<$ $0 \cdot 05$, Student's $t$-test).

tivity of parotid saliva. Conversely, $S$. oralis $34 \mathrm{did}$ not appear to adsorb bPRPs and thus salivary stimulation of C. albicans-S. oralis co-adhesion must occur independently of bPRPs.

\section{Proteins bound by streptococci also support adhesion of $C$. albicans to experimental pellicle}

To determine if the same salivary components that promote binding of C. albicans to streptococci also promote adherence of Candida cells to saliva-treated HA beads, parotid saliva samples were pre-treated with streptococcal cells and then used to coat HA beads. There was a $>50 \%$ reduction in the numbers of $C$. albicans cells binding to HA beads coated with saliva that had been pre-incubated with S. gordonii cells, compared with untreated saliva (Fig. 3). A reduction $(28 \%)$ was also noted in numbers of yeast cells adhering to $S$. oralis-treated saliva-coated beads, but there was no significant effect on the numbers binding to HA beads coated with saliva that had been pre-incubated with $S$. mitis, S. mutans or C. albicans (Fig. 3).

As expected, parotid saliva that had been pre-incubated with $S$. gordonii cells was significantly $(P<0.05, t$-test $)$ reduced in its ability to promote C. albicans-S. gordonii DL1 co-adherence (Fig. 4). By contrast, parotid saliva pre-incubated with $S$. oralis 34 cells, or with C. albicans ATCC 10261, was not significantly reduced in stimulation of co-adhesion (Fig. 4). These data confirm that the major enamel pellicle receptors for C. albicans are also subject to high-affinity adsorption to the cell surface of S. gordonii.

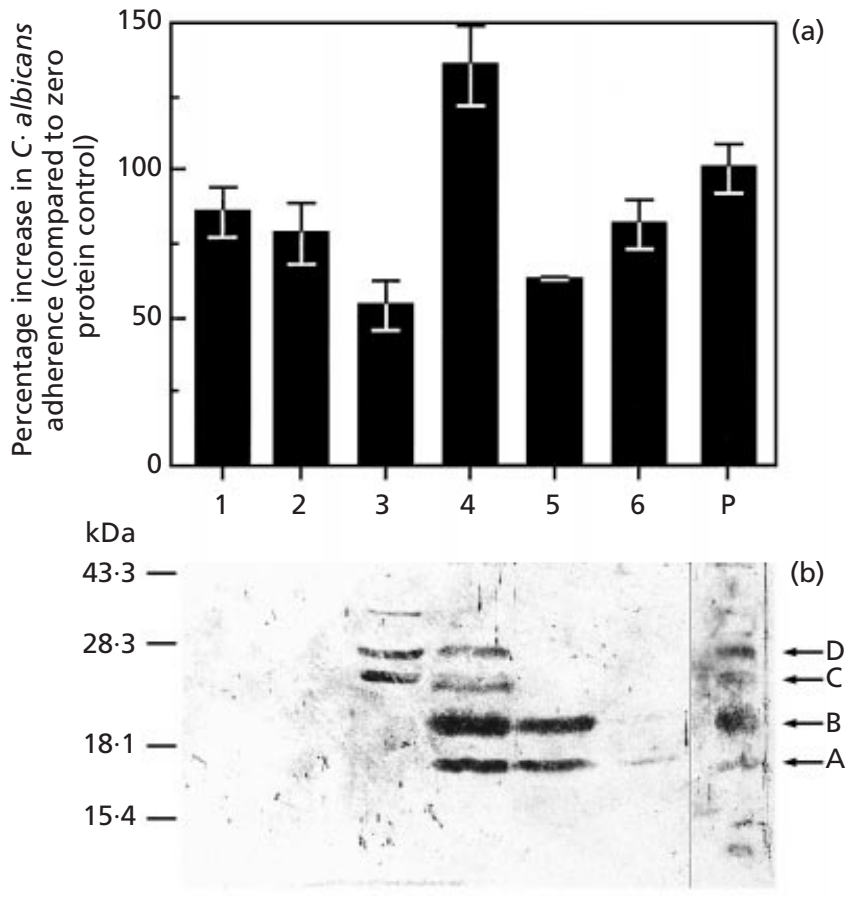

Fig. 5. Saliva proteins that promote adhesion of C. albicans to S. gordonii cells. Pooled parotid saliva was fractionated by Sephacryl S200 column chromatography. Pooled fractions were utilized in microtitre well assays, and subjected to blot overlay analysis. (a) Percentage increase in numbers of C. albicans ATCC 10261 cells adhering to immobilized S. gordonii DL1 coated with salivary proteins from pools 1 through 6 or by parotid saliva ( $P$ ) (approx. $2 \mathrm{pg}$ salivary proteins applied per cell), compared with control (no saliva; $17.5 \pm 0.77 \%$ input cells adhered). Results are the means $( \pm S D)$ of triplicates performed on the same batch of cells. (b) C. albicans ATCC 10261 blot overlay of parotid saliva pool samples in (a). Parotid saliva pools 1-6 (20 $\mu \mathrm{l}$ per lane) and parotid saliva $(P ; 8 \mu \mathrm{g})$ were separated by SDS-PAGE, electroblotted onto nitrocellulose membranes and incubated with radiolabelled $C$. albicans cells $\left(1.1 \times 10^{7}\right.$ cells $\mathrm{ml}^{-1}$ ).

\section{Promotion of C. albicans-streptococcal co-adhesion by parotid salivary protein fractions}

To confirm that the bPRPs within parotid saliva were capable of directly promoting C. albicans adhesion to $S$. gordonii, adhesion-promoting activities in salivary protein fractions obtained following size-exclusion column chromatography were measured (Fig. 5). Pools designated 1 through 6 contained salivary proteins as previously characterized (O'Sullivan et al., 1997), with pool 4 being enriched in bPRP bands A-D (Fig. 5b). The greatest stimulation of $C$. albicans adhesion to $S$. gordonii was associated with pool 4, while protein pools 3 or 5 , which also contained lesser amounts of bPRPs, also promoted adhesion. Pool 1, which contains protein aggregates excluded from the column, also stimulated a high level of C. albicans adhesion to S. gordonii. The ability of pools 1, 2 and 6 to promote C. albicans-S. gordonii co-adhesion indicates that other proteins, or protein complexes, within saliva also act as receptors for 
C. albicans adherence. However, the magnitude of the adherence stimulation obtained with pool 4, containing all four bPRPs, indicates that the bPRPs are of greatest significance.

\section{DISCUSSION}

Colonization of the oral cavity by C. albicans is a crucial step in the sequence of events leading to an infection. Salivary proteins and glycoproteins can act as receptors for binding of C. albicans cells to enamel surfaces (Cannon et al., 1995b) and to denture acrylic surfaces (Vasilas et al., 1992; Edgerton et al., 1993; Nikawa et al., 1993) and can modulate the binding of yeast cells to buccal epithelial cells (Kimura \& Pearsall, 1978; Samaranayake \& MacFarlane, 1982). In addition, C. albicans binding to oral viridans streptococci (Jenkinson et al., 1990; Holmes et al., 1995a, b, 1996) and to Actinomyces (Grimaudo et al., 1996) may be enhanced by salivary components (Holmes et al., 1995a; Grimaudo et al., 1996). We have now determined that the basic PRPs present in human parotid salivary secretions are not only active in providing receptors for adhesion of C. albicans to enamel pellicles, but also that these salivary components are adsorbed by streptococci and act to promote adhesion of C. albicans ATCC 10261 to bacterial cells.

Salivary proteins and glycoproteins are present in multiply active conformations within the human oral cavity. In the fluid phase, salivary components may be present as discrete molecules or more usually as macromolecular complexes often involving mucins (Iontcheva et al., 1997). A number of these components are selectively adsorbed onto enamel, and the aPRPs and statherin change conformation upon binding to enamel (Moreno et al., 1984) thus unmasking receptors for adhesion of streptococci and Actinomyces species (Gibbons \& Hay, 1988; Gibbons et al., 1990, 1991). This ability of oral micro-organisms to bind immobilized salivary proteins is of considerable ecological significance. Adhesins that have evolved to bind immobilized conformations of salivary components provide a mechanism for attachment of microbial cells to oral surfaces despite the presence of excess soluble forms of the receptors within saliva. The bPRPs appear to comprise another group of salivary proteins that act as receptors for microbial cell adhesion when immobilized. Interestingly, the streptococci, in particular S. gordonii, are able to adsorb these proteins to their surfaces and the bound forms then act as receptors for C. albicans adhesion. Conversely, C. albicans cells are unable to adsorb bPRPs from saliva, although small amounts of other macromolecules are adsorbed by yeast cells (Edgerton et al., 1993). Thus C. albicans demonstrates a unique adhesive mechanism whereby adhesion may occur to surface-bound forms of bPRPs despite the presence of excess fluid-phase bPRPs in saliva.

Streptococci are early colonizers of salivary pellicles and their ability to bind salivary proteins and glycoproteins is important in plaque development. Of the strepto- coccal species tested, S. gordonii cells bound salivary proteins to the greatest extent, but the components of saliva bound by the streptococcal species varied quite considerably. The changes to the salivary protein profiles observed following incubation with streptococcal cells were highly reproducible, and evidence suggested that the alterations resulted from adsorption of the proteins to the bacterial cell surface rather than for other reasons such as proteolysis. Even in the presence of a cocktail of protease inhibitors, bPRP bands A, C and D were adsorbed by S. gordonii within $15 \mathrm{~min}$ determined by the overlay assay (data not shown). Previously, $S$. gordonii cells have been reported to bind to PRPs IB-1 to IB-9 and Ps-1 in blot overlay assays (Newman et al., 1996). The adsorption of bPRPs by $S$. gordonii occurs via a high-affinity mechanism since maximal adsorption of bPRPs from the fluid phase occurred under conditions that did not result in the complete removal of $\alpha$-amylase, which is a high-affinity binding reaction (Scannapieco et al., 1989). Pool 4 promotes high binding of C. albicans to immobilized $S$. gordonii cells and it is possible that all four bPRPs are recognized, when presented on the surface of the bacterial cells, with a concomitant increase in binding activity. As a result of adsorption of bPRPs by streptococci, the PRP-depleted saliva was much less efficient at supporting C. albicans adhesion to HA beads, confirming that similar forms of the adhesion receptors are presented by enamel and by streptococci.

S. gordonii is found at multiple sites within the human oral cavity and is associated with numerous intra- and inter-generic bacterial co-aggregations which are postulated to be involved in the formation of oral biofilms (Kolenbrander \& London, 1993; Holmes et al., 1996). Therefore, adhesion of C. albicans cells to salivary components adsorbed to $S$. gordonii cells would potentially increase the number of available sites for $C$. albicans adhesion and colonization. In support of this suggestion, it has been observed that C. albicans cells are more usually found associated with plaque-coated areas of enamel (Arendorf \& Walker, 1980). It could be envisaged that presentation of bPRPs on the surface of streptococci might also tend to co-aggregate C. albicans and promote clearance from the oral cavity. However, streptococcal cells also bind to aPRP 1-coated enamel (Gibbons et al., 1991). Thus direct co-aggregation of $C$. albicans with streptococci, or co-aggregation via bPRP, followed by binding of streptococci to an oral surface could also provide a means by which C. albicans colonization is promoted.

Currently, the molecular nature of the receptor that binds bPRPs to the streptococcal cell surface is not known. However, two protein families on the streptococcal cell surface are known to bind to other salivary proteins. The antigen I/II proteins (Jenkinson \& Demuth, 1997) bind salivary agglutinin glycoprotein while AbpA (Rogers et al., 1998) binds $\alpha$-amylase. The antigen I/II proteins SspA and SspB are also involved in the direct binding of $S$. gordonii to C. albicans cells (Holmes et al., 1996). We have observed that mutants 
deficient in the production of SspA and $\mathrm{SspB}$ are reduced, by approximately $20 \%$, in their ability to adsorb bPRPs (unpublished observations). However, since adsorption of bPRPs by wild-type cells appears to be a rapid and high-affinity process, simply reduced adsorption by the mutants implies that the SspA and SspB proteins are not the major bPRP adhesins. Therefore, it seems likely that the binding of bPRPs to the streptococcal cell surface may occur through a multi-modal mechanism.

In summary, C. albicans cells do not appear to bind salivary bPRPs in the fluid phase. However, adsorption of these proteins to a surface such as enamel, Streptococcus, or to nitrocellulose in vitro exposes receptors that are then recognized by C. albicans cells. This ability to adhere to only surface-bound peptides would enable C. albicans cells to adhere to multiple oral cavity surfaces in the presence of fluid-phase saliva and thus enhance its colonization potential.

\section{ACKNOWLEDGEMENTS}

We thank A.S. Bleiweis, P.S. Handley and P. E. Kolenbrander for providing strains. J. M. O'Sullivan was in receipt of a Targeted Otago Research Grant for part of this work.

\section{REFERENCES}

Arendorf, T. M. \& Walker, D. M. (1979). Oral candidal populations in health and disease. Br Dent J 147, 267-272.

Arendorf, T. M. \& Walker, D. M. (1980). The prevalence and intraoral distribution of Candida albicans in man. Arch Oral Biol 25, $1-10$.

Branting, C., Sund, M. L. \& Linder, L. E. (1989). The influence of Streptococcus mutans on adhesion of Candida albicans to acrylic surfaces in vitro. Arch Oral Biol 34, 347-353.

Cannon, R. D. \& Chaffin, W. L. (1999). Oral colonization by Candida albicans. Crit Rev Oral Biol Med 10, 359-383.

Cannon, R. D., Holmes, A. R., Mason, A. B. \& Monk, B. C. (1995a). Oral Candida: clearance, colonization, or candidiasis? J Dent Res 74, 1152-1161.

Cannon, R. D., Nand, A. K. \& Jenkinson, H. F. (1995b). Adherence of Candida albicans to human salivary components adsorbed to hydroxylapatite. Microbiology 141, 213-219.

Douglas, C. W. \& Russell, R. R. (1984). The adsorption of human salivary components to strains of the bacterium Streptococcus mutans. Arch Oral Biol 29, 751-757.

Douglas, C. W. I., Pease, A. A. \& Whiley, R. A. (1990). Amylasebinding as a discriminator among oral streptococci. FEMS Microbiol Lett 66, 193-198.

Edgerton, M., Scannapieco, F. A., Reddy, M. S. \& Levine, M. J. (1993). Human submandibular-sublingual saliva promotes adhesion of Candida albicans to polymethylmethacrylate. Infect Immun 61, 2644-2652.

Gibbons, R. J. \& Hay, D. I. (1988). Human salivary acidic prolinerich proteins and statherin promote the attachment of Actinomyces naeslundii LY7 to apatitic surfaces. Infect Immun 56, 439-445.

Gibbons, R. J., Hay, D. I., Childs, W. C., 3rd \& Davis, G. (1990). Role of cryptic receptors (cryptitopes) in bacterial adhesion to oral surfaces. Arch Oral Biol 35, 107S-114S.
Gibbons, R. J., Hay, D. I. \& Schlesinger, D. H. (1991). Delineation of a segment of adsorbed salivary acidic proline-rich proteins which promotes adhesion of Streptococcus gordonii to apatitic surfaces. Infect Immun 59, 2948-2954.

Grimaudo, N. J., Nesbitt, W. E. \& Clark, W. B. (1996). Coaggregation of Candida albicans with oral Actinomyces species. Oral Microbiol Immunol 11, 59-61.

Hodson, J. J. \& Craig, G. T. (1972). The incidence of Candida albicans in the plaques of teeth of children. Dent Pract Dent Rec 22, 296-301.

Holmes, A. R. \& Shepherd, M. G. (1988). Nutritional factors determine germ tube formation in Candida albicans. J Med Vet Mycol 26, 127-131.

Holmes, A. R., Cannon, R. D. \& Jenkinson, H. F. (1995a). Interactions of Candida albicans with bacteria and salivary molecules in oral biofilms. J Ind Microbiol 15, 208-213.

Holmes, A. R., Gopal, P. K. \& Jenkinson, H. F. (1995b). Adherence of Candida albicans to a cell surface polysaccharide receptor on Streptococcus gordonii. Infect Immun 63, 1827-1834.

Holmes, A. R., McNab, R. \& Jenkinson, H. F. (1996). Candida albicans binding to the oral bacterium Streptococcus gordonii involves multiple adhesin-receptor interactions. Infect Immun 64, 4680-4685.

Iontcheva, I., Oppenheim, F. G. \& Troxler, R. F. (1997). Human salivary mucin MG1 selectively forms heterotypic complexes with amylase, proline-rich proteins, statherin, and histatins. J Dent Res 76, 734-743.

Jenkinson, H. F. \& Demuth, D. R. (1997). Structure, function, and immunogenicity of streptococcal antigen I/II polypeptides. Mol Microbiol 23, 183-190.

Jenkinson, H. F. \& Lamont, R. J. (1997). Streptococcal adhesion and colonization. Crit Rev Oral Biol Med 8, 175-200.

Jenkinson, H. F., Lala, H. C. \& Shepherd, M. G. (1990). Coaggregation of Streptococcus sanguis and other streptococci with Candida albicans. Infect Immun 58, 1429-1436.

Kimura, L. H. \& Pearsall, N. N. (1978). Adherence of Candida albicans to human buccal epithelial cells. Infect Immun 21, 64-68.

Kolenbrander, P. E. \& London, J. (1993). Adhere today, here tomorrow: oral bacterial adherence. J Bacteriol 175, 3247-3252. Laemmli, U. K. (1970). Cleavage of structural proteins during the assembly of the head of bacteriophage T4. Nature 227, 680-685.

Lamont, R. J. \& Rosan, B. (1990). Adherence of mutans streptococci to other oral bacteria. Infect Immun 58, 1738-1743.

Lynch, D. P. \& Tenn, M. (1994). Oral candidiasis. History, classification, and clinical presentation. Oral Surg Oral Med Oral Pathol 78, 189-193.

McNab, R., Jenkinson, H. F., Loach, D. M. \& Tannock, G. W. (1994). Cell-surface-associated polypeptides CshA and CshB of high molecular mass are colonization determinants in the oral bacterium Streptococcus gordonii. Mol Microbiol 14, 743-754.

Moreno, E. C., Kresak, M. \& Hay, D. I. (1984). Adsorption of molecules of biological interest onto hydroxyapatite. Calcif Tissue Int 36, 48-59.

Newman, F., Beeley, J. A., MacFarlane, T. W., Gailbraith, J. \& Buchanan, L. (1993). Salivary protein interactions with oral bacteria: an electrophoretic study. Electrophoresis 14, 1322-1327.

Newman, F., Beeley, J. A. \& MacFarlane, T. W. (1996). Adherence of oral micro-organisms to human parotid salivary proteins. Electrophoresis 17, 266-270.

Nikawa, H. \& Hamada, T. (1990). Binding of salivary or serum proteins to Candida albicans in vitro. Arch Oral Biol 35, 571-573. 
Nikawa, H., Hayashi, S., Nikawa, Y., Hamada, T. \& Samaranayake, L. P. (1993). Interactions between denture lining material, protein pellicles and Candida albicans. Arch Oral Biol 38, 631-634.

Odds, F. C. (1988). Candida and Candidosis: a Review and Bibliography. London: Baillière Tindall.

O'Sullivan, J. M., Cannon, R. D., Sullivan, P. A. \& Jenkinson, H. F. (1997). Identification of salivary basic proline-rich proteins as receptors for Candida albicans adhesion. Microbiology 143, 341-348.

Pakula, R. \& Walczak, W. (1963). On the nature of competence of transformable streptococci. J Gen Microbiol 31, 125-133.

Rams, T. E. \& Slots, J. (1991). Candida biotypes in human adult periodontitis. Oral Microbiol Immunol 6, 191-192.

Rogers, J. D., Haase, E. M., Brown, A. E., Douglas, C. W., Gwynn, J. P. \& Scannapieco, F. A. (1998). Identification and analysis of a gene $(a b p A)$ encoding a major amylase-binding protein in Streptococcus gordonii. Microbiology 144, 1223-1233.

Rudney, J. D., Ji, Z., Larson, C. J., Liljemark, W. F. \& Hickey, K. L. (1995). Saliva protein binding to layers of oral streptococci in vitro and in vivo. J Dent Res 74, 1280-1288.

Samaranayake, L. P. (1992). Oral mycoses in HIV infection. Oral Surg Oral Med Oral Pathol 73, 171-180.

Samaranayake, L. P. \& MacFarlane, T. W. (1982). Factors affecting the in vitro adherence of the fungal oral pathogen Candida albicans to epithelial cells of human origin. Arch Oral Biol 27, 869-873.

Scannapieco, F. A., Bergey, E. J., Reddy, M. S. \& Levine, M. J. (1989). Characterization of salivary $\alpha$-amylase binding to Streptococcus sanguis. Infect Immun 57, 2853-2863.
Shannon, I. L., Prigmore, J. R. \& Chauncey, H. H. (1962). Modified Carlson-Crittenden device for the collection of parotid fluid. $J$ Dent Res 41, 778-783.

Slots, J., Rams, T. E. \& Listgarten, M. A. (1988). Yeasts, enteric rods and pseudomonads in the subgingival flora of severe adult periodontitis. Oral Microbiol Immunol 3, 47-52.

Stinson, M. W., Haraszthy, G. G., Zhang, X. L. \& Levine, M. J. (1992). Inhibition of Porphyromonas gingivalis adhesion to Streptococcus gordonii by human submandibular-sublingual saliva. Infect Immun 60, 2598-2604.

Towbin, H., Staehelin, T. \& Gordon, J. (1979). Electrophoretic transfer of proteins from polyacrylamide gels to nitrocellulose sheets: procedure and some applications. Proc Natl Acad Sci USA 76, 4350-4354.

Vasilas, A., Molina, L., Hoffman, M. \& Haidaris, C. G. (1992). The influence of morphological variation on Candida albicans adhesion to denture acrylic in vitro. Arch Oral Biol 37, 613-622.

Verran, J. \& Motteram, K. L. (1987). The effect of adherent oral streptococci on the subsequent adherence of Candida albicans to acrylic in vitro. J Dent $15,73-76$.

Whittaker, C. J., Klier, C. M. \& Kolenbrander, P. E. (1996). Mechanisms of adhesion by oral bacteria. Annu Rev Microbiol 50, 513-552.

Wright, P. S., Clark, P. \& Hardie, J. M. (1985). The prevalence and significance of yeasts in persons wearing complete dentures with soft-lining materials. J Dent Res 64, 122-125.

Received 2 August 1999; revised 28 September 1999; accepted 14 October 1999. 